\title{
Influence of Meteorology on Fine Particles Concentration in Vitória Metropolitan Region During Wintertime
}

\author{
Willian Lemker Andreão ${ }^{1}$ (D), Bruna Tuão Trindade $^{2}$, Antônio Paula Nascimento ${ }^{3}$, \\ Neyval Costa Reis Júnior ${ }^{2}$ (D), Maria de Fátima Andrade ${ }^{4}$ (D), \\ Taciana Toledo de Almeida Albuquerque ${ }^{1,2}$ \\ ${ }^{1}$ Departamento de Engenharia Ambiental e Sanitária, Universidade Federal de Minas Gerais, \\ Belo Horizonte, $M G$, Brazil. \\ ${ }^{2}$ Departamento de Engenharia Ambiental, Universidade Federal do Espírito Santo, \\ Vitória, ES, Brazil. \\ ${ }^{3}$ Departamento de Tecnologia Industrial, Universidade Federal do Espirito Santo, \\ Vitória, ES, Brazil. \\ ${ }^{4}$ Departamento de Ciências Atmosféricas, Instituto de Astronomia, Geofísica e Ciências \\ Atmosféricas, Universidade de São Paulo, São Paulo, SP, Brazil.
}

Received: 25 September 2018 - Accepted: 8 January 2019

\begin{abstract}
Fine particles $\left(\mathrm{PM}_{2.5}\right)$ are harmful to human health especially during periods of limited dispersion when the concentrations build up. This is a common occurrence in Southern Brazil in the dry season when high-pressure stationary systems inhibit vertical dispersion and reduce wind speed. The objective of this study was to evaluate the $\mathrm{PM}_{2.5}$ concentrations in the Region of Greater Vitória during the winter of 2013, and to assess the influence of the large-scale meteorological circulation on its concentration. An experimental campaign was carried out to determine the mass of $\mathrm{PM}_{2.5}$ at six urban sites and particle number concentration. The average $\mathrm{PM}_{2.5}$ concentrations varied from $9.70 \mu \mathrm{g} \mathrm{m}^{-3}$ to $14.36 \mu \mathrm{g} \mathrm{m}^{-3}$ with the average daily maximum reaching $29.35 \mathrm{\mu g} \mathrm{m}^{-3}$, exceeding the World Health Organization guideline (24-h average: $25 \mu \mathrm{g} \mathrm{m}^{-3}$ ). The particle size distribution showed a larger number of particles from 18 to $21 \mathrm{~h}$ (local time), indicating that the main vehicular emissions are the main sources. During the winter, rainfall associated with cold fronts were responsible for a decrease in the particulate concentrations. In contrast, the occurrence of high-pressure systems led to an increase in particle concentrations, due to stagnant conditions.
\end{abstract}

Keywords: fine particles, meteorological parameters, urban area, particle counting, particle size distribution, winter.

\section{Influência da Meteorologia Sobre Partículas Finas na Região Metropolitana de Vitória Durante o Inverno}

\begin{abstract}
Resumo
Partículas finas $\left(\mathrm{MP}_{2,5}\right)$ são prejudiciais à saúde humana e em períodos críticos de dispersão, aumentos na concentração de $\mathrm{MP}_{2,5}$ podem ocorrer. Esta é uma ocorrência comum no Sudeste do Brasil no período seco, quando sistemas de altas pressões estacionárias inibem a dispersão vertical e reduzem a velocidade do vento. O objetivo deste estudo foi avaliar as concentrações de partículas finas na Região da Grande Vitória durante o inverno de 2013, e verificar a influência de fenômenos meteorológicos de grande escala em sua concentração. Uma campanha experimental foi realizada para determinar a massa de $\mathrm{MP}_{2,5}$ em seis locais urbanos e concentrações de partículas. As concentrações médias de $\mathrm{MP}_{2,5}$ variaram de $9,70 \mu \mathrm{g} \mathrm{m}^{-3}$ a $14,36 \mu \mathrm{g} \mathrm{m}^{-3}$ nos seis locais amostrados, com o máximo diário médio chegando a $29,35 \mu \mathrm{g} \mathrm{\textrm {m } ^ { - }}$ 3 , excedendo, assim, a diretriz da Organização Mundial da Saúde (média de $24 \mathrm{~h}: 25 \mu \mathrm{g} \mathrm{m}^{-3}$ ). A distribuição granulométrica indicou um maior número de partículas entre $18 \mathrm{~h}$ e $21 \mathrm{~h}$ (hora local), indicando que a principal fonte emissora é
\end{abstract}

Corresponding author: Taciana Toledo de Almeida Albuquerque, taciana@desa.ufmg. 
veicular. Durante o inverno, a precipitação associada com as frentes frias foram os responsáveis pela diminuição da concentração de partículas. Em contraste, a ocorrência de sistemas de alta pressão na região levou a um aumento nas concentrações de partículas, devido a condições de estagnação.

Palavras-chave: partículas finas, parâmetros meteorológicos, área urbana, contagem de partículas, distribuição do tamanho de partículas, inverno.

\section{Introduction}

Air pollution is a serious urban problem related to both local emissions and transboundary pollution and governed by micro and large-scale atmospheric circulation (Beekmann et al., 2015; Diamantopoulou et al., 2016; Shimadera et al., 2016; Sun et al. 2017a). The terrain over any region is generally non-uniform in relation to roughness and thermal characteristics and may contain a complex topography. Consequently, the meteorological parameters that affect transport, diffusion, transformation and removal processes (dry and wet deposition) are functions of time and space. The pollutants emissions associated with topographic and meteorological characteristics determine the levels of air quality over a certain region (Arya, 1999).

Several case studies have shown that meteorological conditions affect ambient air quality (Sánchez-Ccoyllo and Andrade, 2002; Pearce et al., 2011; Ramsey et al., 2014; Tian et al., 2014; Trivedi et al., 2014; Li et al., 2015; Zhang et al., 2015; Monte et al., 2016; Santos et al., 2016; He et al., 2017; Mazzuca et al., 2017; You et al., 2017; Asif et al., 2018; Wie and Moon, 2018). Therefore, atmospheric conditions have a determining role in the physicochemical description of the transport of pollutants between the source and the receiver. Hence, meteorological data analysis, pollutant monitoring and air quality modeling are the main tools for planning new industrial activities and for the establishment of air pollution control policies.

Atmospheric particles can originate from various sources, including human activities, photochemical processes, gas-to-particle conversion, wind erosion, and oceans. Therefore, there is a considerable variation in the composition and physical properties of particles, depending on the sources, as well as on the meteorological conditions and geographic location (Miranda et al., 2012). Fine particulate matter $\left(\mathrm{PM}_{2.5}\right.$, particles with a diameter $<2.5 \mu \mathrm{m}$ ) can remain airborne for days, weeks, and even months, traveling many hundreds of kilometers from their source (Seinfeld and Pandis, 2006).

The Greater Region of Vitória (RGV) is a tropical coastal area, and it has an estimated population of 1.8 million inhabitants and is the main urban and industrial area in the State of Espírito Santo (Brazil) (IBGE, 2017). About 55 to $65 \%$ of the potentially polluting industrial activities of Espírito Santo, such as steel, pelletizing, mining (quarries), cement, food industry, asphalt plant and others, are installed in the RGV (IEMA, 2011). The climate of RGV is warm and humid (Köpper climate type
Af). This climate type is characterized by mild dry winter and hot rainy summer. The warm period extends approximately from October to April, with greater intensity in December and January. During the winter, the region is influenced by the South Atlantic Subtropical High (SASH) pressure system, which is a tropical marine mass, with high temperatures and humidity, resulting from intense solar radiation and seawater evaporation. In winter, the anticyclone displaces toward the continent and inhibit the passage of the frontal systems, providing a stable atmosphere, with calm winds, often accompanied by thermal inversion (Reboita et al., 2012; Sun et al., 2017b).

According to the RGV Emission Inventory report (IEMA, 2011), the emission rate of total particulate matter (vehicular and industrial) in RGV was $4,043.1 \mathrm{~kg} \mathrm{~h}^{-1}$, of which $1,487.5 \mathrm{~kg} \mathrm{~h}^{-1}$ was $\mathrm{PM}_{2.5}$, which means that $\mathrm{PM}_{2.5}$ emissions account for $36 \%$ of particulate emissions from the region. Approximately $60 \%$ of particulate emissions were directly or indirectly linked to the resuspension of particles in traffic roads. The air quality monitoring in the $\mathrm{RGV}$ is performed by an automatic air quality monitoring network (RAMQAr), measuring the ambient concentration of air pollutants of total particulate matter (TPM), particles with a diameter of less than $10 \mu \mathrm{m}\left(\mathrm{PM}_{10}\right)$, sulfur dioxide $\left(\mathrm{SO}_{2}\right)$, oxides of nitrogen $\left(\mathrm{NO}_{\mathrm{x}}\right)$, hydrocarbons $(\mathrm{HC})$, carbon monoxide $(\mathrm{CO})$, ozone $\left(\mathrm{O}_{3}\right)$ and settleable particulate matter (coarser particles with diameters greater than $10 \mu \mathrm{m}$, which are the bulk constituent in mass - manual monitoring network). The monitoring of fine particles started recently.

Among pollutants that can cause harm to human health and loss of quality of life, fine particles stand out as a pollutant that can cause both short and long-term health problems in humans, leading to the loss of life quality and eventually death (Pope III et al., 2002; Krewski et al., 2009; Cesaroni et al., 2013; Nascimento et al., 2017; Andreão et al., 2018). This research aims to contribute to the knowledge of the characteristics of the particulate material in RGV, where continuous measurements are scarce or non-existent, through its quantification and size distribution, besides to observe the influence of the main meteorological systems of synoptic scale acting in the region during the critical period of the winter of 2013 in the variability of $\mathrm{PM}_{2.5}$ concentrations.

\section{Experimental Methods and Study Area}

$\mathrm{PM}_{2.5}$ were sampled with six MiniVol TAS (Tactical Air Sampler) (Airmetrics) in six of the nine monitoring stations which are part of the Automatic Air Quality Mon- 
itoring Network (RAMQAr) during the winter of 2013 (June to September) to evaluate the air quality and the variations in the concentrations of the particles in different parts of the region. Laranjeiras station suffers direct influence of Ponta de Tubarão industries (iron ore) when the south winds occur, and influence of the northern industries when the occurrence of northeast winds. Jardim Camburi station covers areas directly influenced by emissions from industries of Ponta de Tubarão, Serra and Vitória. It is also influenced by mobile sources circulating in its surround areas. The Enseada do Suá station is presented as the main station in the installed measurement network, since it is located strategically, providing a large space coverage area. In addition, it is directly influenced by the Ponta de Tubarão and by the mobile sources. Vitória (center) station provides spatial coverage of areas directly influenced by vehicle emissions and receives contributions from port activities and industrial sources of Vitória and Vila Velha. Ibes station covers areas directly influenced by the vehicular and industrial emissions of Vitória, Vila Velha and Cariacica. Lastly, Cariacica station has a high coverage in the southwestern part of the region, with low redundancy among other network stations, covering areas directly influenced by emissions of vehicles and industries (IEMA, 2017).

The Laser Aerosol Spectrometer (LAS) (Portable Aerosol Spectrometer model 1.109 GRIMM AEROSOL), a laser used for continuous measurement of airborne particles as well as for measuring the particle count distribution, was used to obtain the particle number size distribution. The apparatus emits a laser beam and the scattering by particles caused by the passage of a particle is measured by calculating the aerosol size range and counting the particles in that range. The data are provided in the unit number of particles per liter allowing quantifying particles between $0.25 \mu \mathrm{m}$ to $32.0 \mu \mathrm{m}$, which correspond to the particles of the accumulation and coarse modes. All data collected is stored on a memory card in the device and, using an RS-232 cable and DustMonitor software, is transferred to a computer where it can be analyzed. The results provided by the apparatus are the particle number $(\mathrm{PN})$ per liter in 31 particle diameters ranges from $0.25 \mu \mathrm{m}$ to $32.0 \mu \mathrm{m}$. The equipment was placed in the Federal University of Espírito Santo (UFES), operating $24 \mathrm{~h}$ per day between August $7^{\text {th }}$ and September $2^{\text {nd }}$ (except for August $16^{\text {th }}$ and $17^{\text {th }}$ ), resulting in 24 days analyzed. Figure 1 shows the sampling places of MiniVol and LAS.

The sampling period with MiniVol was from June $21^{\text {st }}$ to September $21^{\text {st }}$, on alternate days, $24 \mathrm{~h}$ of filter exposure, which totaled 47 days. The MiniVol was calibrated to standard conditions of atmospheric pressure $(760 \mathrm{~mm} \mathrm{Hg})$ and temperature $(298 \mathrm{~K})$ and adjusted to operate at a flow rate of $5.0 \mathrm{~L} \mathrm{~min}^{-1}$ under these conditions. The real flow rate in each equipment for each day was obtained using mean values of temperature and pressure from a meteorological station located at UFES and the regression curve for calibration of each equipment, according to Eq. (1).

$$
Q_{\text {real }}=\left(m_{\text {vol }} \times Q_{\text {ind }}+b_{\text {vol }}\right) \times \sqrt{\frac{P_{\text {sta }}}{P_{\text {real }} \times} \frac{T_{\text {real }}}{T_{\text {sta }}}}
$$

where $Q_{\text {real }}$ is the flow rate in operating conditions (L $\left.\min ^{-1}\right) ; Q_{\text {ind }}$ is the flow rate indicated by the sampler rotary $\left(\mathrm{L} \mathrm{min}^{-1}\right) ; m_{v o l}$ and $b_{v o l}$ are, respectively, the slope and the intersection of the linear regression curve, specific data of each apparatus, provided by the calibration curve that accompanies each MiniVol; $P_{\text {sta }}$ is the standard pression and $T_{\text {sta }}$ is the a temperature in standard conditions; $P_{\text {real }}$ is the pression and $T_{\text {real }}$ is the temperature in operation conditions.

$\mathrm{PM}_{2.5}$ was collected on Whatman teflon filters $46.2 \mathrm{~mm}$ in diameter, with $99.7 \%$ retention efficiency for particles up to $0.3 \mu \mathrm{m}$. In this procedure, the filters were placed in petri dishes and stored in an appropriate desiccator, with a temperature maintained between $20{ }^{\circ} \mathrm{C}$ to $23{ }^{\circ} \mathrm{C}$ and relative humidity between $30 \%$ and $40 \%$, according to guidelines of the monitoring standard for $\mathrm{PM}_{2.5}$ of the American Environmental Protection Agency (U.S. EPA, 1998).

The material collected by the MiniVol was analyzed by gravimetric analysis to obtain the $\mathrm{PM}_{2.5}$ mass. Before and after each sampling, each filter is weighed, and the difference in mass results in the total mass collected. For weighing, the Sartorius analytical balance was used with a precision of $0.001 \mathrm{mg}$. Weighing of "blank field" and "blank laboratory" filters were performed. "Blank field" filters are non-sampled filters, which have been taken to the sampling sites and returned to the conditioning conditions, and "blank laboratory" are non-sampled filters that have been kept in wrapping during the sampling period. Both are used to determine possible contamination or loss of material during the transport/handling/packaging processes of the filters. Following the criteria of the U.S. EPA (1998), a blank field was performed every seven samples, and a blank laboratory at each weighing which in this case was performed every approximately 15 days. Blank field filters with a variation greater than $30.0 \mu \mathrm{g}$ and blank laboratory filters with a variation greater than $15.0 \mu \mathrm{g}$ generate very high uncertainties and thus all the filters sampled during that week should be discarded. The number of valid samples is shown in Table 1.

The total air volume sampled was calculated integrating the air uptake rate and the sampling time. Once the masses were determined, the $\mathrm{PM}_{2.5}$ concentration of the filter was calculated. The blank filter that generated the greatest uncertainty was used as the uncertainty of the measurements of all the samples of that period. 

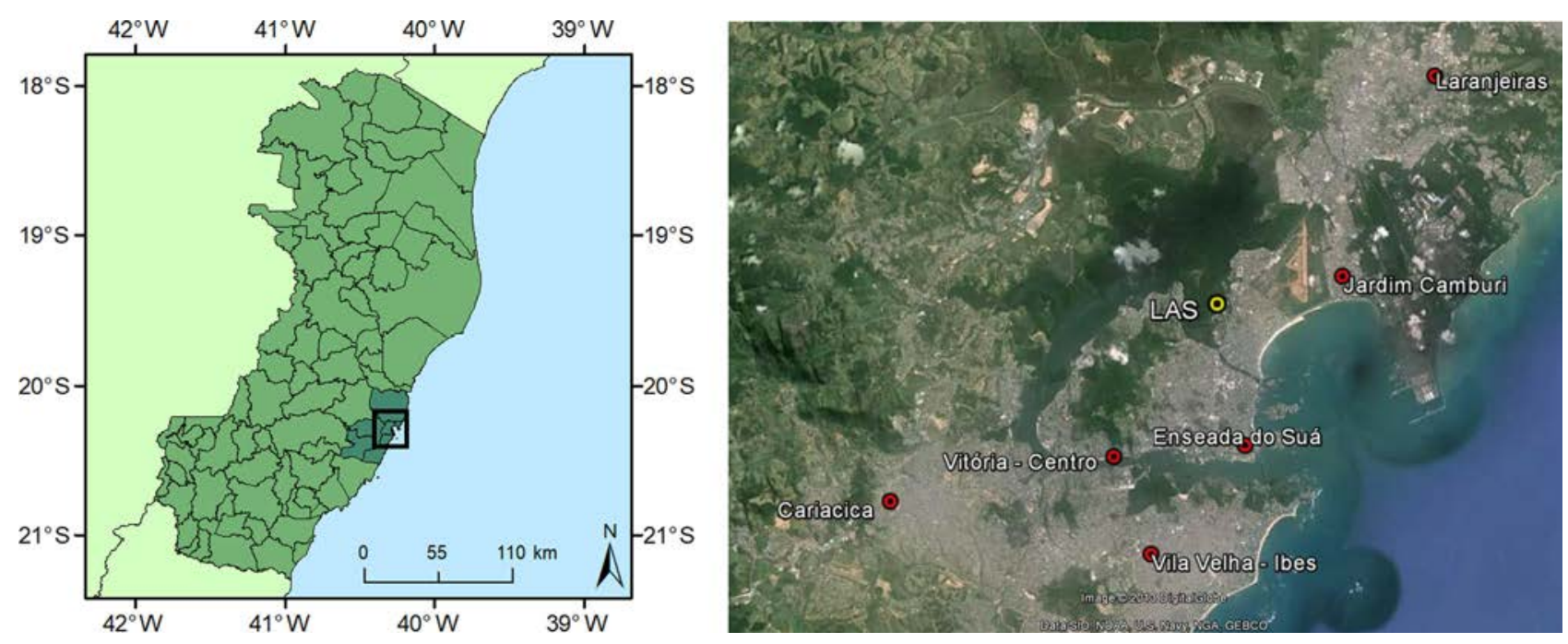

Figure 1 - Sampling places with MiniVol (in red) and with LAS (in yellow). Source: Google Earth.

Table 1 - $\mathrm{PM}_{2.5}$ statistics.

\begin{tabular}{|c|c|c|c|c|c|}
\hline Locality & $\mathrm{N}^{\circ}$ of valid samples & Winter average $\left(\mu \mathrm{g} / \mathrm{m}^{3}\right)$ & $24 \mathrm{~h}$ maximum $\left(\mu \mathrm{g} / \mathrm{m}^{3}\right)$ & $24 \mathrm{~h}$ minimum $\left(\mu \mathrm{g} / \mathrm{m}^{3}\right)$ & $\overline{\text { Standard deviation }}$ \\
\hline Laranjeiras & 47 & 11.98 & 19.39 & 5.27 & 3.69 \\
\hline J. Camburi & 42 & 14.36 & 29.35 & 6.14 & 5.11 \\
\hline Enseada do Suá & 47 & 9.70 & 19.25 & 4.84 & 3.26 \\
\hline Vitória Centro & 46 & 10.17 & 21.48 & 3.30 & 4.23 \\
\hline Ibes & 46 & 10.41 & 22.26 & 3.13 & 4.84 \\
\hline Cariacica & 47 & 12.16 & 27.99 & 4.87 & 5.20 \\
\hline
\end{tabular}

During the sampling period, the synoptic charts published by the Centro de Previsão de Tempo e Estudos Climáticos (CPTEC/INPE) were obtained in their website and they provided the synoptic occurrences of the period, as cold fronts and SASH. In addition, the monthly synoptic summaries, also available on the CPTEC website, were collected.

Hourly temperature, humidity and precipitation were obtained from a meteorological station located at UFES operated by the Instituto Nacional de Meteorologia (INMET). Wind speed and wind direction were obtained from the Rede de Meteorologia do Comando da Aeronáutica (REDEMET) located at the airport of Vitória.

\section{Results}

\subsection{Weather conditions of the period}

During the winter of 2013, the mean temperature was $22.3{ }^{\circ} \mathrm{C}$, coinciding with the normal climatological for the period. The passage of the cold fronts resulted in a decrease in the daily average temperature. August was unusually rainy (Fig. 2), with $95 \mathrm{~mm}$, compared to the climatological average of $40 \mathrm{~mm}$. July was the second most rainy month, with cumulative rainfall of $70.6 \mathrm{~mm}$, against $85 \mathrm{~mm}$ of the normal climatological. The months of June and September presented cumulative rainfall of $21.45 \mathrm{~mm}$ and $23.8 \mathrm{~mm}$, respectively, below the normal climatological of $65 \mathrm{~mm}$ (June) and $90 \mathrm{~mm}$ (September). In general, the winter of 2013 was atypical in relation to the precipitation, and these patterns reflected in the $\mathrm{PM}_{2.5}$ concentrations measured in the RGV.

The wind rose presented in Fig. 3 shows the velocity and the directions of the wind for the whole winter. The prevailing wind directions for the first two months of winter, June and July, were N-NW, S-SW-SE, with the highest speeds coming mainly from the $\mathrm{SW}$ and $\mathrm{N}$ directions. August presented the same configuration, but with wind velocities higher than those of the previous months, which was already expected because this was the wettest month of the studied period. September is a transition month and it showed an increase in the frequency of prevailing winds in the NE direction, which, climatologically, should be the predominant direction during the rest of the year. Occurrences of south/southwest quadrant winds are related to cold fronts events. The velocity range of 0.5 to $2.0 \mathrm{~m} \mathrm{~s}^{-1}$ occurred in $40 \%$ of the time, while wind velocities of 2.1 to $3.5 \mathrm{~m} \mathrm{~s}^{-1}$ occurred in $15.7 \%$ of the time, 3.6 to $5.6 \mathrm{~m} \mathrm{~s}^{-1}$, in $25.6 \%, 5.7$ to $8.7 \mathrm{~m} \mathrm{~s}^{-1}$, in $12.6 \%$, and 8.8 to $11 \mathrm{~m} \mathrm{~s}^{-1}$, in $1.9 \%$ of the time. Calm winds corresponded to $4.1 \%$ of the time.

In relation to the synoptic systems operating in the region, according to the synoptic charts (CPTEC/INPE), a 

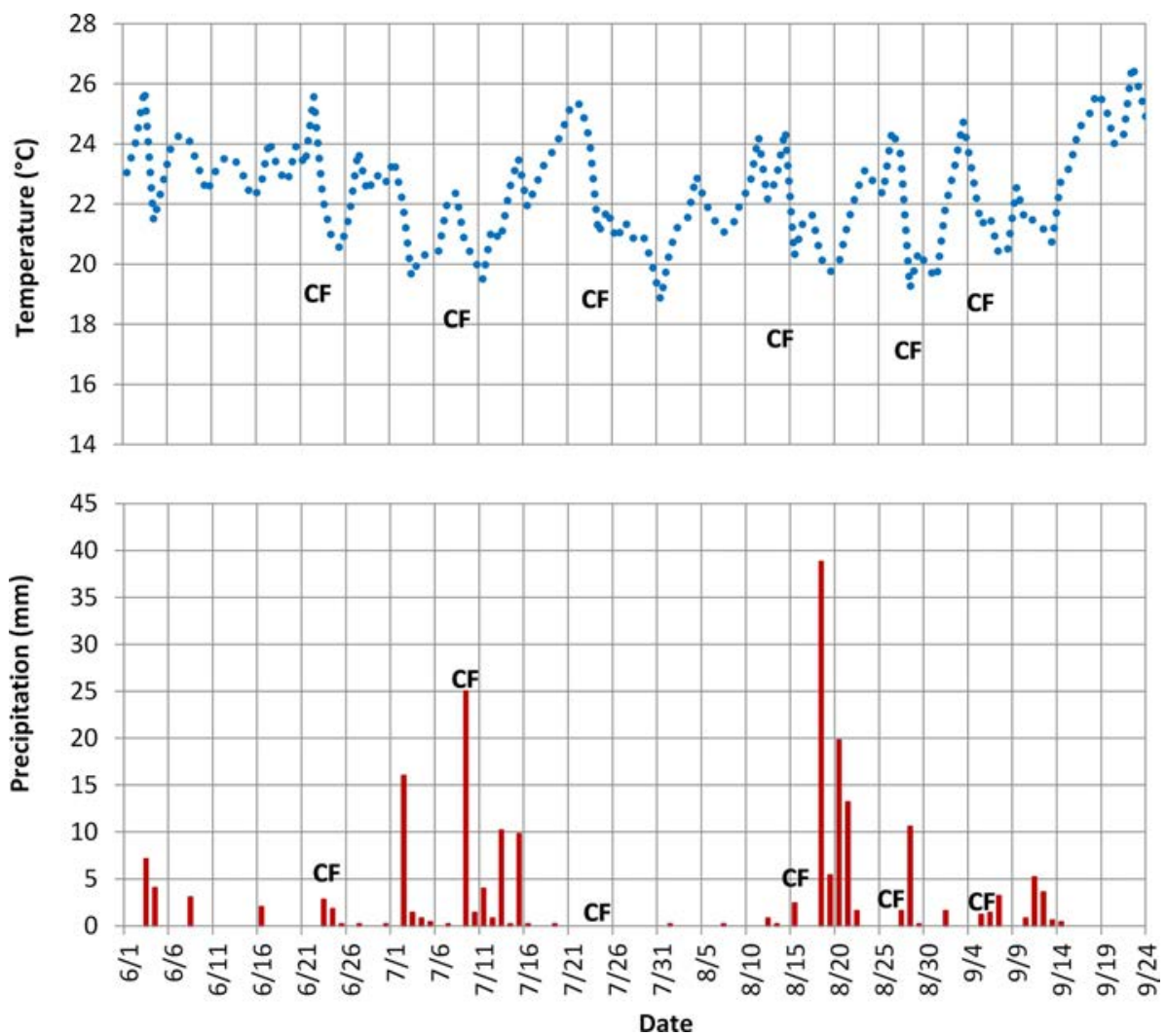

Figure 2 - Average temperature and precipitation during the winter. CF: cold front incidence.

WHOLE WINTER

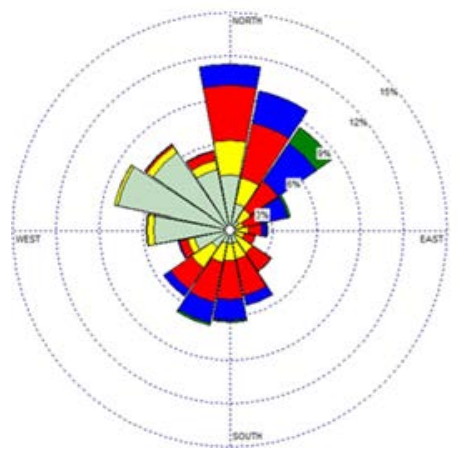

wind velocity $\left(\mathrm{m} \mathrm{s}^{-1}\right)$

$\square>=11$

$8.8-10.9$

$5.7-8.7$

$3.6-5.6$

2.1 - 3.5

$0.5-2.0$

Figure 3 - Wind rose for Winter 2013.

total of six cold fronts reached the RGV during the winter of 2013 (June $23^{\text {rd }}$, July $09^{\text {th }}$, July $24^{\text {th }}$, August $15^{\text {th }}$, August $27^{\text {th }}$, September $05^{\text {th }}$ ). In all occurrences of cold front there was a drop in the temperature in relation to the previous day, and in most occurrences, it rained. There was also a change in the direction of the wind, as shown in Fig. 4, which starts to blow predominantly from the south and southwest, with an increase in wind speed compared to the previous day, which contributes to the transport and dilution of pollutants. During most of winter, a high-pressure center was acting on the State of Espírito Santo. However, it is emphasized that only one meteorological

monitoring station was used to represent the whole region (a coastal area with a complex topography), and smallscale circulation, as sea breeze, may affect wind direction across the $\mathrm{PM}_{2.5}$ sampling sites (Salvador et al., 2016a; 2016b).

\subsection{Gravimetric analysis of $P M_{2.5}$}

The winter average concentration of $\mathrm{PM}_{2.5}, 24 \mathrm{~h}$ maximum and minimum values, standard deviation and quantity of valid samples are shown in Table 1 for each sampled locality. Jardim Camburi, a predominantly residential neighborhood of Vitória, obtained the higher average $\left(14.36 \mu \mathrm{g} \mathrm{m}^{-3}\right)$ and the maximum value $\left(29.35 \mu \mathrm{g} \mathrm{m}^{-3}\right)$, followed by Cariacica. Both maximum values are higher than those recommended by WHO ( $24 \mathrm{~h}$ average: $25 \mu \mathrm{g} \mathrm{m}^{-3}$ ). In these days, the SASH was acting over the region. The minimum value $\left(3.13 \mu \mathrm{g} \mathrm{m}^{-3}\right)$ was found in Ibes (Vila Velha).

Jardim Camburi and Cariacica have emission sources very close to the sampling point, which may have directly influenced the concentration values of $\mathrm{PM}_{2.5}$. In Jardim Camburi there is a steakhouse close to the monitoring point and therefore, the results may be evaluated carefully. Cariacica sampling point is close to two federal roads (BR-101 and BR-262) with high traffic of heavy vehicles. 


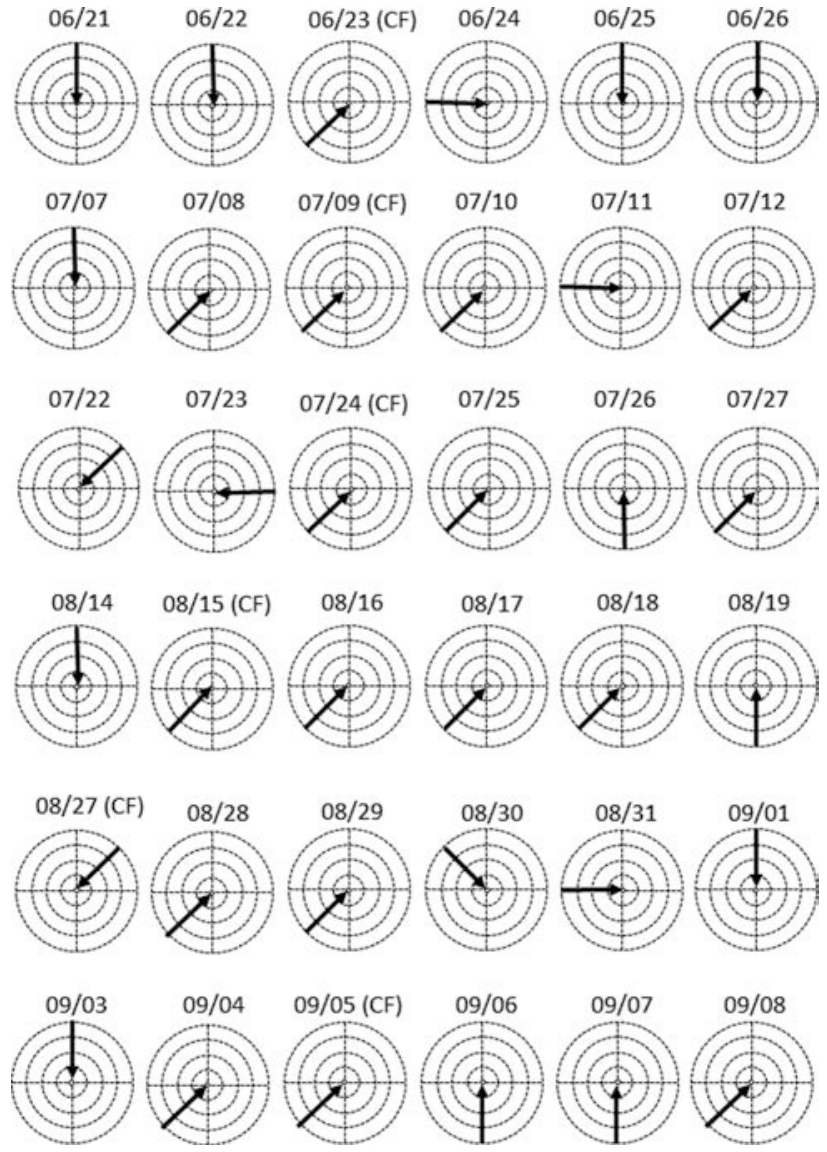

Figure 4 - Daily average wind direction of the six cold fronts (CF), with arrows pointing to where the wind predominantly blew on the day.

The $\mathrm{PM}_{2.5}$ concentrations found in $\mathrm{RGV}$ are similar to the $\mathrm{PM}_{2.5}$ concentrations in urban centers as Belo Horizonte, Curitiba, Porto Alegre, and Recife (14.7, 14.4, 13.4, and $7.3 \mu \mathrm{g} \mathrm{m}{ }^{-3}$, respectively), as reported by Andrade et al. (2012), where vehicle emissions explained at least $40 \%$ of the $\mathrm{PM}_{2.5}$ mass. Miranda et al. (2012) reported $\mathrm{PM}_{2.5}$ concentration of $35.5 \mu \mathrm{g} \mathrm{m}^{-3}$ in the winter of São Paulo, $19.8 \mu \mathrm{g} \mathrm{m}^{-3}$ in Rio de Janeiro, $17.9 \mu \mathrm{g} \mathrm{m}^{-3}$ in Belo Horizonte, $18.1 \mu^{\mathrm{g} \mathrm{m}^{-3}}$ in Curitiba, $18.3 \mu \mathrm{g} \mathrm{m}^{-3}$ in Porto Alegre, and $8.7 \mu \mathrm{g} \mathrm{m}^{-3}$ in Recife. Targino et al. (2016) measured $\mathrm{PM}_{2.5}$ and $\mathrm{BC}$ concentrations along roads in Londrina (Paraná) on selected days in March and
April 2015, and a mean $\mathrm{PM}_{2.5}$ concentration of $8.61 \mu \mathrm{g} \mathrm{m}^{-3}$ for morning period, and $8.43 \mu \mathrm{g} \mathrm{m}^{-3}$ for afternoon period were found, values below than those found in RGV, but the PM was measured in the rainy season in Londrina. Vara-Vela et al. (2016) reported average $\mathrm{PM}_{2.5}$ concentration at three measurement sites in São Paulo between July and September 2012: $23.4 \mu \mathrm{g} \mathrm{m}^{-3}$ in IPEN-USP, $21.3 \mu \mathrm{g}$ $\mathrm{m}^{-3}$ in IAG-USP, and $22.2 \mu \mathrm{g} \mathrm{m}^{-3}$ in Congonhas.

Table 2 shows the $\mathrm{PM}_{10}$ winter average concentration, $24 \mathrm{~h}$ maximum and minimum values, and standard deviation, measured in the RAMQAr monitoring stations. The average ratio $\mathrm{PM}_{2.5} / \mathrm{PM}_{10}$ concentrations for winter period was possible to perform in five station: $35.9 \%$ in Laranjeiras, $57.2 \%$ in Carapina, 33.5\% in Enseada do Suá, $42.9 \%$ in Vitória Centro, and $35.8 \%$ in Ibes. According to the official emission inventory for RGV (IEMA, 2011), $53.7 \%$ of the $\mathrm{PM}_{10}$ emitted (vehicular and industrial) was $\mathrm{PM}_{2.5}$. This percentage reflected in the concentration ratio observed. Souza et al. (2014) showed higher percentages for São Paulo during winter $(73.4 \%)$ and percentages similar to this work for Piracicaba during spring (51.4\%). The differences for São Paulo can be related to the fuel burning used in light vehicles (Galvão et al., 2016; Pacheco et al., 2017) and the formation of secondary aerosols by converting gas to particle (Albuquerque et al., 2018).

Table 3 shows some meteorological information about the days when the higher concentrations of $\mathrm{PM}_{2.5}$ occurred. There was no precipitation in any of the days, except for the September $13^{\text {th }}$ at Jardim Camburi station, where there was a rainfall of $0.6 \mathrm{~mm}$, caused by mesoscale atmospheric phenomena (sea breeze), as can be verified by the predominant wind direction variation throughout the day (NW-N-NE). In general, the wind velocity was low in the days of higher $\mathrm{PM}_{2.5}$ concentration, characteristic of SASH, which predominated over the region on most of these days. Except on days July $23^{\text {rd }}$ and $31^{\text {st }}$, every day had predominant wind direction ranging from NW-N-NE. July $23^{\text {rd }}$, the day with the maximum concentration in Enseada do Suá, had contributions of south wind due to the arrival of the extremely strong and historic cold front that passed over Brazil between July $21^{\text {st }}$ and $25^{\text {th }}$. The average wind velocity of the day was $4.7 \mathrm{~m} \mathrm{~s}^{-1}$ and after

Table 2 - $\mathrm{PM}_{10}$ statistics (RAMQAr monitoring stations).

\begin{tabular}{lcccc}
\hline Locality & Winter average $\left(\mu \mathrm{g} / \mathrm{m}^{3}\right)$ & $24 \mathrm{~h}$ maximum $\left(\mu \mathrm{g} / \mathrm{m}^{3}\right)$ & $24 \mathrm{~h} \mathrm{minimum}\left(\mu \mathrm{g} / \mathrm{m}^{3}\right)$ & Standard deviation \\
\hline Laranjeiras & 33.37 & 64.09 & 11.27 & 13.46 \\
Carapina & 15.89 & 34.48 & 7.63 & 4.70 \\
J. Camburi & 25.12 & 47.08 & 12.71 & 7.18 \\
Enseada do Suá & 28.97 & 46.30 & 12.42 & 6.25 \\
Vitória Centro & 23.68 & 49.29 & 11.17 & 7.26 \\
Ibes & 29.07 & 55.54 & 10.17 & 8.33 \\
Vila Velha Centro & 24.96 & 39.21 & 11.00 & 6.27 \\
\hline
\end{tabular}


Table 3 - Meteorological information about the day with the highest $\mathrm{PM}_{2.5}$ concentration.

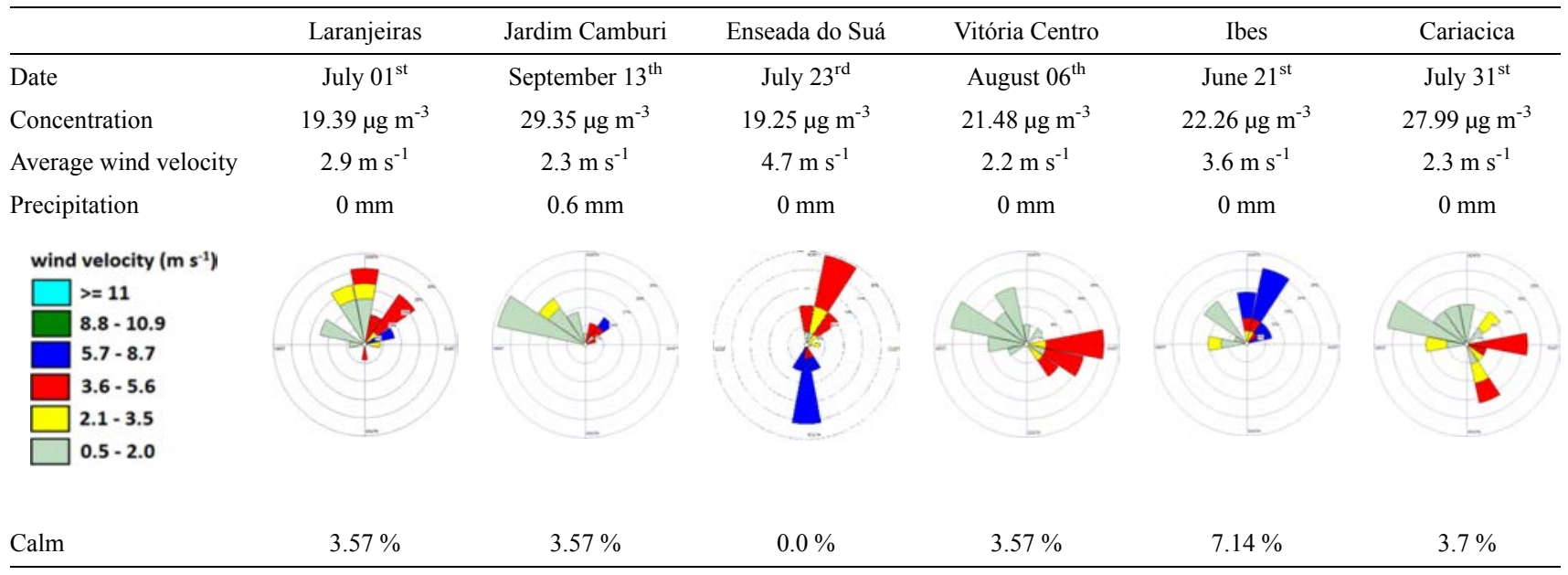

the cold front passage, the temperature dropped down from $25.1{ }^{\circ} \mathrm{C}$ (July $23^{\text {rd }}$ ) to $22.5^{\circ} \mathrm{C}$ (July $25^{\text {th }}$ ) and the $\mathrm{PM}_{2.5}$ concentration decreased $5.58 \mu \mathrm{g} \mathrm{m}^{-3}$.

Figures 5 and 6 show the temporal variation of $\mathrm{PM}_{2.5}$ concentration, indicating the days of cold front incidence (CF). After the passage of the cold fronts, a decrease in $\mathrm{PM}_{2.5}$ concentrations may be noted. Observed rains between August $18^{\text {th }}$ and $22^{\text {nd }}$, the most voluminous of the period, were also responsible for a drop in $\mathrm{PM}_{2.5}$ concentrations for most of the points sampled, being possible to observe a reduction of approximately $10 \mu \mathrm{g} \mathrm{m}^{-3}$ in the concentration of some localities.

In some sampling points, as Larajeiras and Jardim Camburi, the concentration varies according to the wind velocity. This shows that the concentration of fine particulate in these places may be influenced by the resuspension of soil particles, which is accentuated by high wind velocities. In others, such as Ibes and Cariacica, the concentration varies inversely to the wind velocity, showing that in these places the wind plays an important role in transport and dispersion of pollutants. Figure 7 shows the daily average for $\mathrm{PM}_{2.5}$ concentration and wind velocity for Jardim Camburi and Cariacica. The wind velocity data was obtained from RAMQAr monitoring stations.

\subsection{Size distribution in number}

Through the data collected by the LAS, it was possible to perform the particle number distribution as a function of diameter on a time scale. Figure 8 shows the fine particle $(0.25$ to $2.5 \mu \mathrm{m})$ size distributions $\left(\mu \mathrm{m}^{-1} \mathrm{~cm}^{-3}\right)$, normalized by the length of each diameter bin (average of $3 \mathrm{~h}$ ). The time zone with the highest concentration of $\mathrm{PM}_{2.5}$ is from 6 p.m. to 8 p.m. (local time), followed by the bands from 9 p.m. to 11 p.m. and 3 p.m. to 5 p.m. These hours, mainly from 5 p.m. to 9 p.m., are characterized by an increase in traffic rate (IEMA, 2011) and a decrease of the atmospheric boundary layer, which causes an increase in the number of particles in the atmosphere, exceeding the average of 25 particles $\mathrm{cm}^{-3}$ for the smallest diameter range analyzed $(0.25-0.28 \mu \mathrm{m})$. It is emphasized

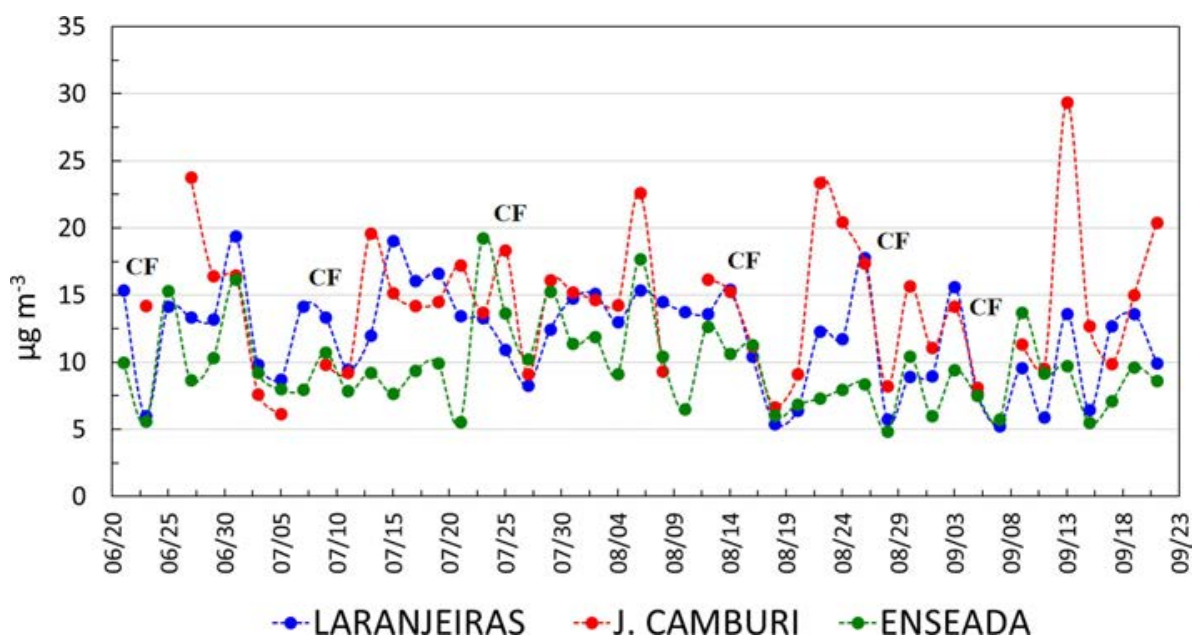

Figure 5 - Variation of the $\mathrm{PM}_{2.5}$ concentration during the sampled period for the localities: Laranjeiras, Jardim Camburi e Enseada do Suá. 


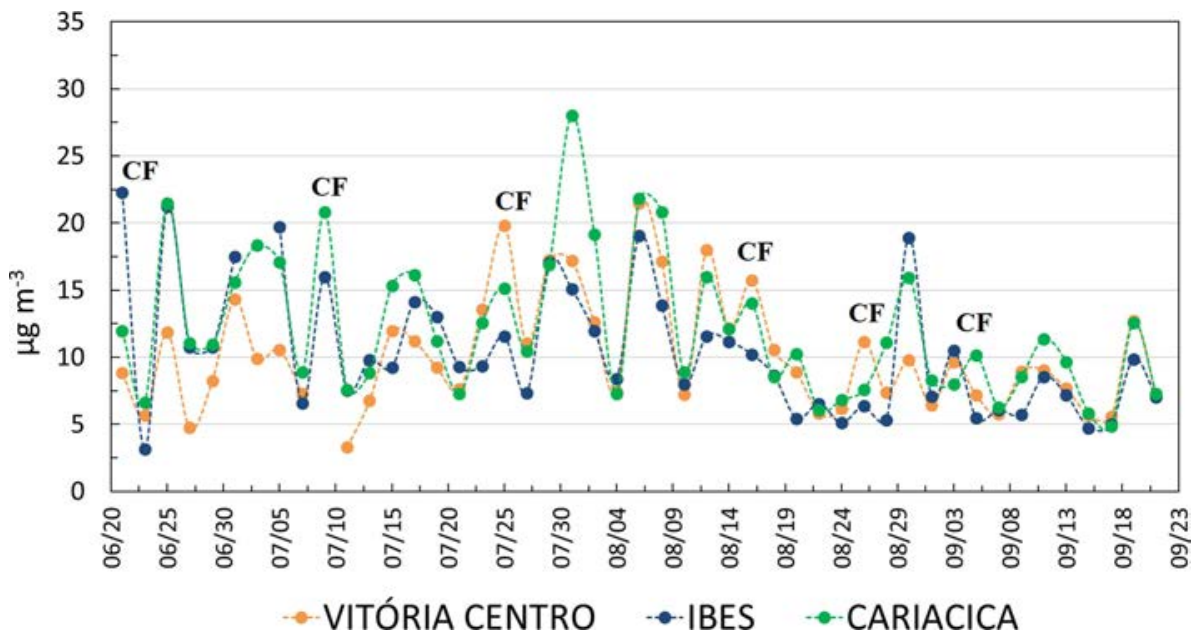

Figure 6 - Variation of the $\mathrm{PM}_{2.5}$ concentration during the sampled period for the localities: Vitória Centro, Ibes e Cariacica.
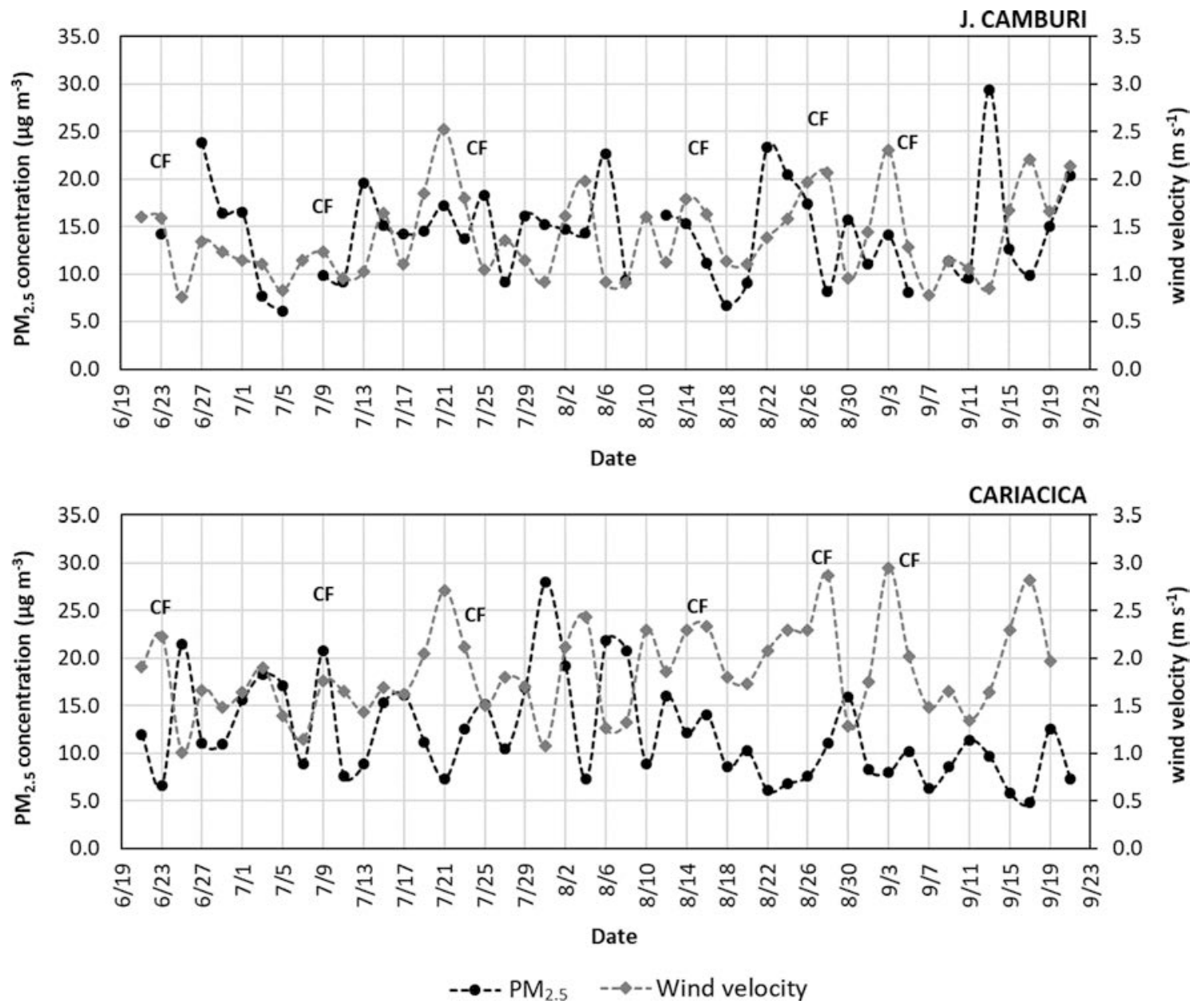

Figure 7 - Time series for daily average of $\mathrm{PM}_{2.5}$ concentration and wind speed at Jardim Camburi and Cariacica.

that the total fine particle concentration may be underestimated, since the LAS only detected particles above $0.25 \mu \mathrm{m}$. The mean diurnal cycle of the total particle number concentration is shown in Fig. 9 for weekdays and weekend. The diurnal variability of particle size distributions confirmed the 6 p.m. to 8 p.m. as the period with the highest number of particles per $\mathrm{cm}^{3}$, which may also be associated with the dynamics of the boundary layer. The 


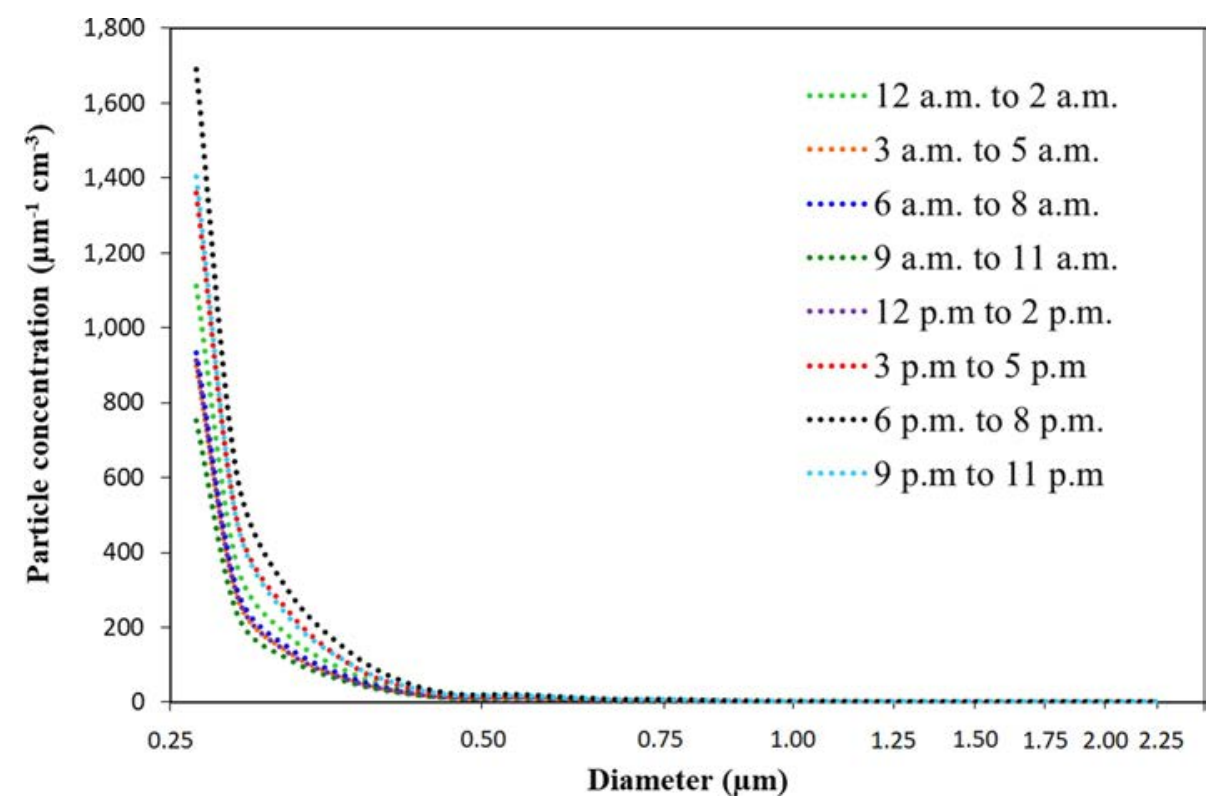

Figure 8 - Number size distribution as a function of diameter for the particles of the accumulation mode, with averages every $3 \mathrm{~h}$.

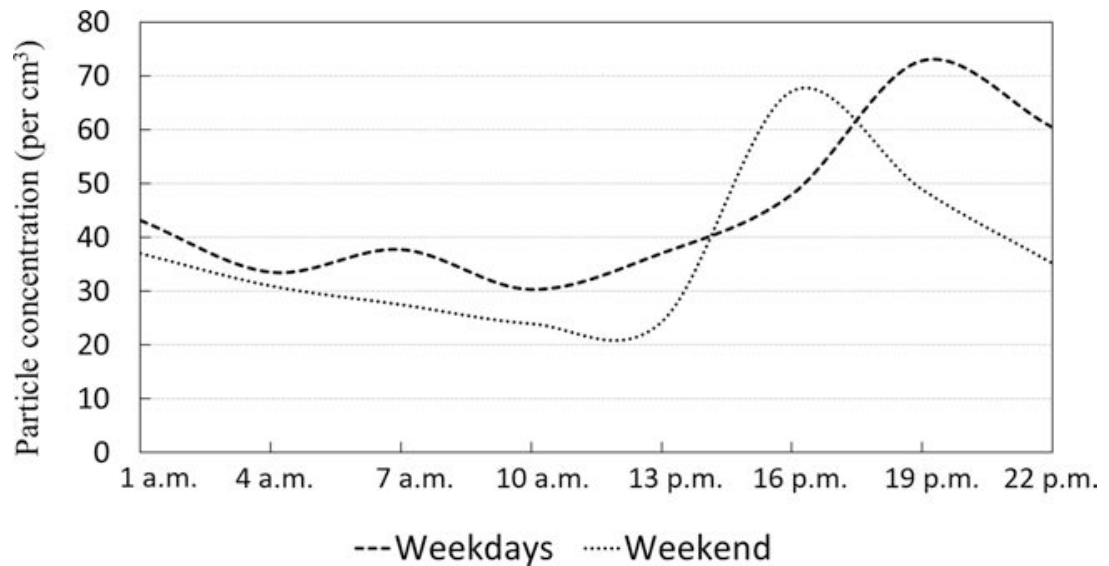

Figure 9 - Number size distribution for weekdays and weekend.

hourly cycle of relative humidity varied inversely proportional to the hourly cycle of temperature in 2013 winter, with higher values during the night period (IEMA, 2017). High values of relative humidity favor the partition of semi-volatile species into the aerosol phase (Hu et al., 2008), leading to an increase in PM concentrations (Zhang et al., 2015).

Figure 10 shows the particle concentration (number per $\mathrm{cm}^{3}$ ) in hourly averages for the entire sampled period, as the sum of the channels from $0.25 \mu \mathrm{m}$ to $32.0 \mu \mathrm{m}$. The first large peak of concentration of the sampled period occurs already on first day of analysis at 9 p.m., caused by the combination of low wind speed and intense vehicular traffic schedule. In general, it can be affirmed that the peaks of concentration verified throughout the period are related to the high-flow time zone of vehicles (5 p.m. to 10 p.m.) (IEMA, 2011) and sometimes to low wind speeds. In August $15^{\text {th }}$ and $27^{\text {th }}$ night, when there were cold fronts in the region, the wind speed increased slightly, and precipitation occurred, resulting in considerably reducing on the number of particles. August $18^{\text {th }}$ and $27^{\text {th }}$ obtained low concentrations in number of particles, due to the incidence of rains.

The fine particles reached concentration of 20 thousand particles per $\mathrm{cm}^{3}$ while coarse particles (diameter > $2.5 \mu \mathrm{m}$ ) reached concentration of 55 particles per $\mathrm{cm}^{3}$. The results obtained by the LAS also allowed to evaluate the difference in the number of suspended particles in the atmosphere in relation to the days of the week. Weekend days have lower particle concentrations in number compared to week days. As an example, there were an average about 29 particles per $\mathrm{cm}^{3}$ (particles of diameters between 


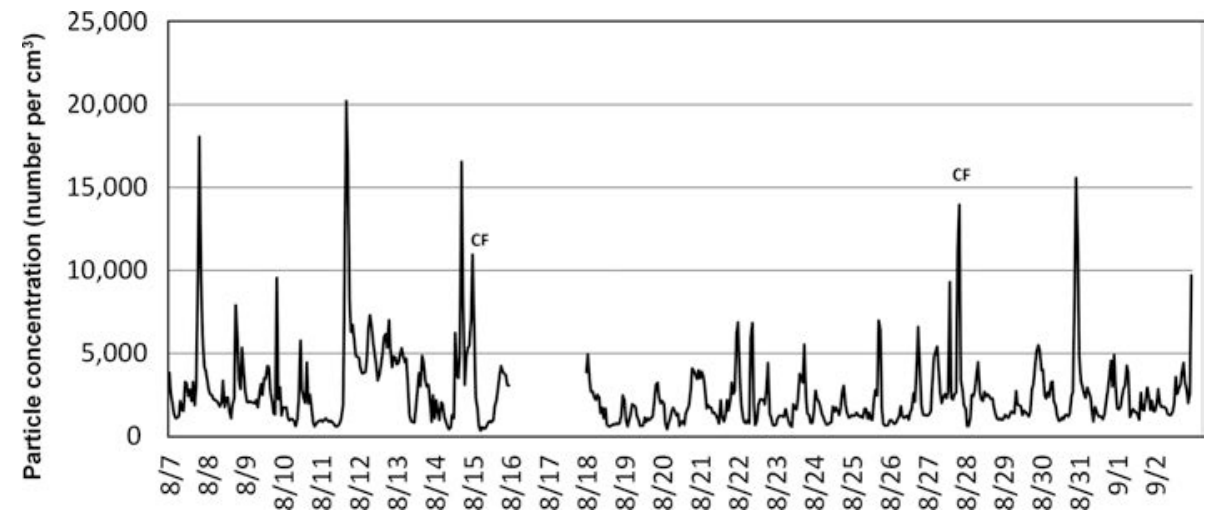

Figure 10 - Total number of particles per hour for the entire sampled period.

0.25 and $0.28 \mu \mathrm{m}$ ) during weekdays, while an average of 23 particles per $\mathrm{cm}^{3}$ were observed during weekends. In addition, the hours of greater concentration change from the range 6 p.m. to 11 p.m. from weekdays to the afternoon on weekends, between 3 p.m. and 5 p.m.

\section{Conclusions}

In relation to the days of highest concentrations in each locality, it was observed that these days, in general, were days without rain, in which the South Atlantic Subtropical High was acting on the region, days marked by winds with low velocities and directions predominant from NW-N-NE, which indicates the contribution of local traffic and industries in the region.

It could be observed that the concentration of fine particulate matter, both in number and mass, is directly influenced by the meteorological phenomena of the synoptic scale in the winter period, when these phenomena are of great importance in the atmospheric circulation. The highest $\mathrm{PM}_{2.5}$ concentration observed was from 6 p.m. to 8 p.m. (local time).

In addition, although the $\mathrm{PM}_{2.5}$ exceeded the mass concentration recommended by the WHO only two times, it presented concentrations very close to that limit throughout the studied period, justifying the need for an attention to this pollutant in the region, in view of its consequences for human health.

\section{Acknowledgments}

This research was partially funded by Fundação de Amparo à Pesquisa do Espírito Santo (FAPES), Conselho Nacional de Desenvolvimento Científico e Tecnológico (CNPq) and Coordenação de Aperfeiçoamento de Pessoal de Nível Superior (CAPES), Brazil.

\section{References}

ALBUQUERQUE, T.T.A.; ANDRADE, M.F.; YNOUE, R.Y.; MOREIRA, D.M.; ANDREÃO, W.L.; SANTOS, F.S.; NASCIMENTO, E.G.S. WRF-SMOKE-CMAQ modeling system for air quality evaluation in São Paulo megacity with a 2008 experimental campaign data. Environ. Sci. Pollut. Res., v. 25, n. 36, p. 36555-36569, 2018.

ANDRADE, M.F.; MIRANDA, R.M.; FORNARO, A.; KERR, A.; OYAMA, B. Vehicle emissions and $\mathrm{PM}_{2.5}$ mass concentrations in six Brazilian cities. Air Qual. Atmos. Health, v. 5, n. 1, p. 79-88, 2012.

ANDREÃO, W.L.; ALBUQUERQUE, T.T.A.; KUMAR, P. Excess deaths associated with fine particulate matter in Brazilian cities. Atmos. Environ, v. 194, p. 71-81, 2018.

ARYA, S.P. Air Pollution, Meteorology and Dispersion, New York: Oxford University Press, 1999.

ASIF, Z.; CHEN, Z.; GUO, J. A study of meteorological effects on $\mathrm{PM}_{2.5}$ concentration in mining area. Atmos. Pollut. Res., v. 9, n. 4, p. 688-696, 2018.

BEEKMANN, M.; PRÉVÔT, A.S.H.; DREWNICK, F.; SCIARE, J.; PANDIS, S.N.; et al. In situ, satellite measurement and model evidence on the dominant regional contribution to fine particulate matter levels in the Paris megacity. Atmos. Chem. Phys., v. 15, p. 9577-9591, 2015.

CESARONI, G.; BADALONI, C.; GARIAZZO, C.; STAFOGGIA, M.; SOZZI, R.; DAVOLI, M.; FORASTIERE, F. Long-term exposure to urban air pollution and mortality in a cohort of more than a million adults in Rome. Environ. Health Persp., v. 121, n. 3, p. 324-331, 2013.

DIAMANTOPOULOU, M.; SKYLLAKOU, K.; PANDIS, S.N. Estimation of the local and long-range contributions to particulate matter levels using continuous measurements in a single urban background site. Atmos. Environ., v. 134, p. 1-9, 2016.

GALVÃO, E.S.; SANTOS, J.M.; REIS JUNIOR, N.C.; STUETZ, R.M. Volatile organic compounds speciation and their influence on ozone formation potential in an industrialized urban area in Brazil. Environ. Technol., v. 37, n. 17, p. 2133-2148, 2016.

HE, J.; GONG, S.; LIU, H.; AN, X.; YU, Y.; et al. Influences of meteorological conditions on interannual variations of particulate matter pollution during winter in the Beijing-Tian- 
jin-Hebei area. J. Meteorol. Res., v. 31, n. 6, p. 1062-1069, 2017.

HU, X.-M.; ZHANG, Y.; JACOBSON, M.Z.; CHAN, C.K. Coupling and evaluating gas/particle mass transfer treatments for aerosol simulation and forecast. J. Geo-phys. Res., v. 113, D11208, n. D11, 2008.

IEMA - Instituto Estadual de Meio Ambiente e Recursos Hídricos do Estado do Espírito Santo. Inventário de emissões atmosféricas da Região da Grande Vitória, Vitória: IEMA, 2011.

IEMA - Instituto Estadual de Meio Ambiente e Recursos Hídricos do Estado do Espírito Santo. Relatório da Qualidade do Ar Grande Vitória 2013, Vitória: IEMA, 2017.

KETZEL, M.; OMSTEDT, G.; JOHANSSON, C.; DURING, I.; POHJOLA, M.; et al. Estimation and validation of $\mathrm{PM}_{2.5} /$ $\mathrm{PM}_{10}$ exhaust and non-exhaust emission factors for practical street pollution modelling. Atmos. Environ., v. 41, n. 40, p. 9370-9385, 2007.

KREWSKI, D.; JERRETT, M.; BURNETT, R.T.; MA, R.; HUGHES, E.; et al. Extended follow-up and spatial analysis of the American Cancer Society study linking particulate air pollution and mortality. HEI Research Report 140. Boston: Health Effects Institute, 2009.

LI, Y.; CHEN, Q.; ZHAO, H.; WANG, L.; TAO, R. Variations in $\mathrm{PM}_{10}, \mathrm{PM}_{2.5}$ and $\mathrm{PM}_{1.0}$ in an urban area of the sichuan basin and their relation to meteorological factors. Atmosphere-Basel, v. 6, n. 1, p. 150-163, 2015.

MAZZUCA, G.M.; PICKERING, K.E.; CLARK, R.D.; LOUGHNER, C.P.; FRIED, A.; et al. Use of tethersonde and aircraft profiles to study the impact of mesoscale and microscale meteorology on air quality. Atmos. Environ., v. 149 , p. $55-69,2017$.

MIRANDA, R.M.; ANDRADE M.F.; FORNARO, A.; ASTOLFO, R.; ANDRE, P.A.; SALDIVA, P. Urban air pollution: a representative survey of $\mathrm{PM}_{2.5}$ mass concentrations in six Brazilian cities. Air Qual. Atmos. Health, v. 5, n. 1, p. 63-77, 2012.

MONTE, E.Z.; ALBUQUERQUE, T.T.A.; REISEN, V.A. Impactos das variáveis meteorológicas na qualidade do ar da Região da Grande Vitória, Espírito Santo, Brasil. Rev. Brasil. Meteorol., v. 31, n. 4, p. 546-554, 2016.

NASCIMENTO, A.P.; SANTOS, J.M.; MILL, J.G.; SOUZA, J.B.; REIS JÚNIOR, N.C.; REISEN, V.A. Association between the concentration of fine particles in the atmosphere and acute respiratory diseases in children. Rev. Saúde Pública, v. 51, 3, 2017.

PACHECO, M.T.; PARMIGIANI, M.M.M.; ANDRADE, M.F.; MORAWSKA, L.; KUMAR, P. A review of emissions and concentrations of particulate matter in the three metropolitan areas of Brazil. J. Transp. Health, v. 4, p. 53-72. 2017.

PANT, P.; HARRISON, R.M. Estimation of the contribution of road traffic emissions to particulate matter concentrations from field measurements: A review. Atmos. Environ., v. 77, p. 78-97, 2013.

PEARCE, J.L.; BERINGER, J.; NICHOLLS, N.; HYNDMAN, R.J.; TAPPER, N.J. Quantifying the influence of local meteorology on air quality using generalized additive models. Atmos. Environ., v. 45, n. 6, p. 1328-1336, 2011.
POPE III, C.A.; BURNETT, R.T.; THUN, M.J.; CALLE, E.E.; KREWSKI, D., ITO, K.; THURSTON, G.D. Lung cancer, cardiopulmonary mortality, and long-term exposure to fine particulate air pollution. J. Amer. Med. Assoc., v. 287, n. 9, p. 1132-1141, 2002.

RAMSEY, N.R.; KLEIN, P.M.; MOORE III, B. The impact of meteorological parameters on urban air quality. Atmos. Environ., v. 86, p. 58-67, 2014.

REBOITA, M.S.; KRUSCHE, N.; AMBRIZZI, T.; ROCHA, R.P.D. Entendendo o tempo e o clima na América do Sul. Terra e Didatica, v. 8, p. 34-50, 2012.

SALVADOR, N.; REIS JR., N.C.; SANTOS, J.M.; ALBUQUERQUE, T.T.A.; LORIATO, A.G.; et al. Evaluation of weather research and forecasting model parameterizations under sea-breeze conditions in a North Sea coastal environment. J. Meteorol. Res., v. 30, n. 6, p. 998-1018, 2016 a.

SALVADOR, N.; LORIATO, A.G.; SANTIAGO, A.; ALBUQUERQUE, T.T.A.; REIS JR., N.C.; et al. Study of the thermal internal boundary layer in sea breeze conditions using different parameterizations: Application of the WRF model in the Greater Vitória Region. Rev. Brasil. Meteorol., v. 31, n.4, p. 593-609, 2016 b.

SÁNCHEZ-CCOYLLO, O.R.; ANDRADE M.F. The influence of meteorological conditions on the behavior of pollutants concentrations in São Paulo, Brazil. Environ. Pollut., v. 116, n.2, p. 257-263, 2002.

SANTOS, T.C.; CARVALHO, V.S.B.; REBOITA, M.S. Avaliação da influência das condições meteorológicas em dias com altas concentrações de material particulado na Região Metropolitana do Rio de Janeiro. Eng. Sanit. Ambient., v. 21 n. 2, p. 307-313, 2016.

SEINFELD, J.H.; PANDIS, N.S. Atmospheric Chemistry and Physics: From Air Pollution to Climate Change, 2. ed., New Jersey: John Wiley \& Sons, 2006.

SHIMADERA, H.; KOJIMA, T.; KONDO, A. Evaluation of air quality model performance for simulating long-range transport and local pollution of $\mathrm{PM}_{2.5}$ in Japan. Advances in Meteorology, v. 2016, ID 5694251, 2016.

SOUZA, D.Z.; VASCONCELLOS, P.C.; LEE, H.; AURELA, M.; SAARNIO, K.; TEINILÄ, K.; HILLAMO, R. Composition of $\mathrm{PM}_{2.5}$ and $\mathrm{PM}_{10}$ collected at urban sites in Brazil. Aerosol Air Qual. Res., v. 14, n. 1, p. 168-176, 2014.

SUN, J.; HUANG, L.; LIAO, H.; LI, J.; HU, J. Impacts of regional transport on particulate matter pollution in China: a review of methods and results. Current Pollution Reports, v. 3, n. 3, p. 182-191, 2017a.

SUN, X.; COOK, K.H.; VIZY, E.K. The South Atlantic Subtropical High: climatology and interannual variability. J. Climate, v. 30, p. 3279-3296, 2017 b.

TARGINO, A.C.; GIBSON, M.D.; KRECL, P.; RODRIGUES, M.V.C.; SANTOS, M.M.; CORRÊA, M.P. Hotspots of black carbon and PM2.5 in an urban area and relationships to traffic characteristics. Environ. Pollut., v. 218, p. 475486, 2016.

TIAN, G.; QIAO, Z.; XU, X. Characteristics of particulate matter (PM10) and its relationship with meteorological factors during 2001-2012 in Beijing. Environ. Pollut., v. 192, p. $266-274,2014$. 
TRIVEDI, D.K.; ALI, K.; BEIG, G. Impact of meteorological parameters on the development of fine and coarse particles over Delhi. Sci. Total Environ., v. 478, p. 175-183, 2014.

U.S. EPA - UNITED STATES ENVIRONMENTAL PROTECTION AGENCY. Quality assurance guidance document - Model quality assurance project plan for the $\mathbf{P M}_{2.5}$ ambient air monitoring program at state and local air monitoring stations (SLAMS). Draft Report, $n^{\circ}$. EPA454/R-98-005, Research Triangle Park: U.S. EPA, 1998.

VARA-VELA, A.; ANDRADE, M.F.; KUMAR, P.; YNOUE, R.Y.; MUÑOZ, A.G. Impact of vehicular emissions on the formation of fine particles in the Sao Paulo Metropolitan Area: A numerical study with the WRF-Chem model. Atmos. Chem. Phys., v. 16, p. 777-797, 2016.

WIE, J.; MOON, B.-K.; Impact of the Western North Pacific Subtropical High on summer surface ozone in the Korean Peninsula. Atmos. Pollut. Res., v. 9, n. 4, p. 655-661, 2018.
YOU, T.; WU, R.; HUANG, G.; FAN, G. Regional meteorological patterns for heavy pollution events in Beijing. $\mathbf{J}$. Meteorol. Res., v. 31, n. 3, p. 597-611, 2017.

ZHANG, H.; WANG, Y.; HU, J.; YING, Q.; HU, X.-M. Relationships between meteorological parameters and criteria air pollutants in three megacities in China. Environ. Res., v. 140, p. $242-254,2015$.

\section{Internet Resources}

IBGE - Instituto Brasileiro de Geografia e Estatística, 2017: https://cidades.ibge.gov.br (accessed on 31 January 2018).

CPTEC/INPE - Centro de Previsão de Tempo e Estudos Climáticos: http://www.cptec.inpe.br (accessed on 31 January 2018).

License information: This is an open-access article distributed under the terms of the Creative Commons Attribution License (type CC-BY), which permits unrestricted use, distribution and reproduction in any medium, provided the original article is properly cited. 